\title{
下水污泥を利用した燃料作物栽培による 温室効果ガス排出削減効果
}

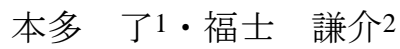 \\ 1正会員 東京大学 環境安全研究センター（干113-0033 東京都文京区本郷7-3-1） \\ E-mail: honda@esc.u-tokyo.ac.jp \\ 2正会員 東京大学 サスティナビリティ学連携研究機構 地球持続戦略研究イニシアティブ \\ ( (113-8654東京都文京区本郷7-3-1) \\ E-mail: fukushi@ir3s.u-tokyo.ac.jp
}

\begin{abstract}
下水污泥の有効利用と下水処理における創エネルギ一施策として, 下水污泥由来の堆肥を利用して燃料 作物を栽培してバイオ燃料を生産した場合の温室効果ガスの排出削減効果を試算した. 政令指定都市およ び特別区にある下水処理場から排出される污泥全量を利用して大豆を栽培しバイオディーゼル（BDF）を 生産した場合，下水処理部門の $4.0 \%$ に相当する温室効果ガス排出削減効果があることがわかった. 一方で, 同一都道府県の耕作放棄地のみを栽培に用いた場合の削減量は，トウモロコシと大豆の場合でそれぞれ下 水処理部門の $0.60 \%, 0.62 \%$ となり, 燃料作物の作付面積が削減量の主要な制限因子となりうることが分か った. 污泥堆肥量が作付面積の制限因子となったため, 面積当たりの施肥量が小さい大豆を生産した方が より多くの温室効果ガス排出削減が見込めることがわかった.
\end{abstract}

Key Words : fuel crop, biofuel, sewage treatment plants, greenhouse gases reduction

\section{1. 序論}

下水道事業からの温室効果ガス総排出量は, 約6.8 百 万t- $-\mathrm{CO}_{2}$ （2005年度）であり，日本全体からの排出量の 0.5\%を占めている ${ }^{1)}$. 日本政府は，2020年までに1990年 比25\%の温室効果ガス削減を目指しており, 下水処理場 においてもさらなる省エネルギー・創エネルギーの努力 が必要となると考えられる. 資源有效利用の観点から, 下水污泥の堆肥利用が進められているが，下水污泥を利 用した堆肥は重金属污染などの懸念や，より高いレベル の食への安全性の要求等から, 国内では農業生産におけ る需要は高くない. しかしながら, 下水污泥由来の堆肥 を食料生産ではなく燃料作物生産へ利用寸ることで，そ の利用促進を図るとともに，下水中のリンなどの栄養塩 の有効利用が可能となる可能性がある. 一方, 全国の耕 作放棄地は, 減反政策や農家の後継者不足により年々増 加しており 2)，その有効利用が求められている.

本研究では, 下水污泥を堆肥化し燃料作物栽培に用い たときのエネルギー創出効果と温室効果ガス排出削減効 果を検証することを目的とし，政令指定都市および特別 区の下水処理場から排出される下水污泥由来の堆肥を用 いて，トウモロコシを栽培してバイオエタノールを生産
した場合と，大豆を栽培してバイオディーゼル（BDF） を生産した場合に得られるバイオ燃料量とその利用によ る温室効果ガス排出削減効果を検証した. 本研究では, 燃料作物の栽培地として, 耕作放棄地を利用した場合と 経営耕地の作付作物を燃料作物に転作した場合の削減量 ポテンシャルについて試算を行った.

\section{2. 研究方法}

\section{（1）下水污泥由来の堆肥生産量}

17政令指定都市および東京都区部が運営する下水処理 場および污泥処理場（121箇所）を，下水道統計 ${ }^{3}$ より 抽出し, 処理場ごとの污泥発生量, 污泥含水率, 処理水 量, 処理水中の窒素およびリン濃度等のデータを得た. 污泥含水率のデータがない場合, 99\%と仮定した. 流域 下水道は解析には含めなかった. 污泥中の窒素及びリン 酸 $\left(\mathrm{P}_{2} \mathrm{O}_{5}\right)$ 含量とC/N比は, 「下水污泥の農地・緑地利用マ ニュアル」 ${ }^{4}$ の乾燥污泥の值から，それぞれ $4.01 \%, 3.62 \%$, 6.53とした。 污泥堆肥化による窒素減量は, Kirchmann ${ }^{5}$ のN-loss式(1)より，48.2\%とした. 


$$
R_{\text {Noss }}=0.559031-0.01108 \times r_{C N}
$$

（1）肥量は，各都道府県における施肥基準 ${ }^{822}$ を参考にして， 以下の手順で決定した（表-1）.

$R_{N \text { loss }}$ : 堆肥化による窒素減量

$r_{C N}:$ 堆肥原料のC/N比.

\section{（2）燃料作物の単位面積当たり収量および施肥量}

燃料作物として，トウモロコシ（スイートコーン） および大豆を選定した. 各都道府県における単位面積当 たりの収量を農林水産統計データのっより得た（表-1）.

また, 燃料作物栽培における面積当たりの污泥堆肥の施

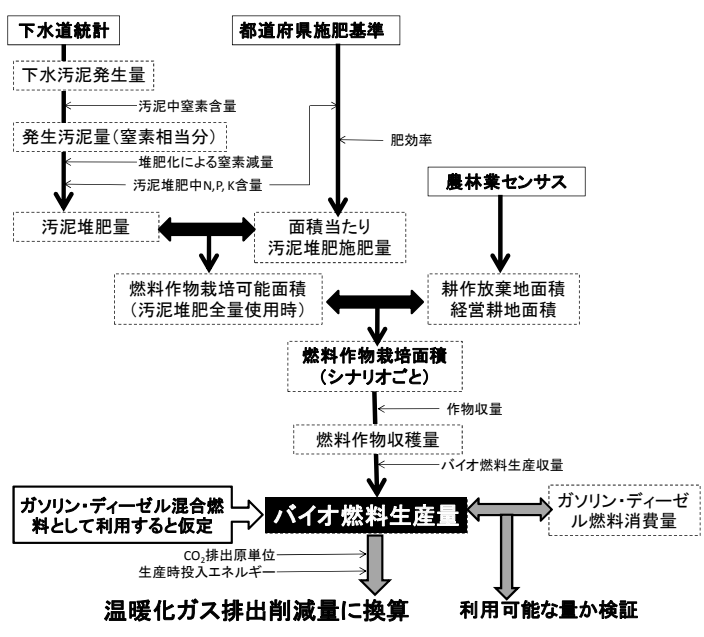

図-1 バイオ燃料生産量の計算フロー (i) 堆肥施用量が基肥基準に従う場合

窒素，リン酸，カリの寸べての肥効成分について，基 肥基準の施肥量を超えないように, 式(2)を用いて污泥 堆肥施肥量を決定した ${ }^{12)}$. 污泥堆肥施肥量に上限が決め られている場合にはそれを超えないようにした。

$$
L=C \times E \times R
$$
$L:$ 有効成分量
$C:$ 肥効成分含量
$E:$ 肥効率
$R:$ 化成肥料との代替率

(ii) 基肥基準と別に堆肥施用量基淮がある場合

各都道府県の施肥基準が想定している堆肥の種類（牛 臯堆肥）を基準量だけ施用した場合の各肥効成分量をそ れぞれ式(2)より算出し，堆肥基準想定有効成分量とし

た．污泥堆肥施肥量は，すべての肥効成分について堆肥 基準想定有効成分量を超えないような施肥量を式(2)よ

り算出した. 新潟県と兵庫県のトウモロコシ栽培, 兵庫 県と佐賀県の大豆栽培の基準に準じた場合にこの計算方 法を用いた。

牛粪堆肥の成分組成は, 窒素 $2.1 \%$, リン酸 $2.1 \%$, 力

表-1 政令指定都市および特別区における污泥堆肥施肥量（窒素換算）と単位面積収量

\begin{tabular}{|c|c|c|c|}
\hline 都道府県 & 都市 & $\begin{array}{c}\text { 施肥量 } \\
{[\mathrm{kgN} / 10 \mathrm{a}]}\end{array}$ & $\begin{array}{c}\text { 収量 } \\
{[\mathrm{kg} / 10 \mathrm{a}]}\end{array}$ \\
\hline 北海道 & 札幌市 & 14 & 1280 \\
\hline 宮城県 & 仙台市 & 54 & 467 \\
\hline 埼玉県 & さいたま市 & 34 & 1170 \\
\hline 千葉県 & 千葉市 & 51 & 986 \\
\hline 東京都 & 東京都区部 & 17 & 931 \\
\hline 神奈川県 & 横浜市 & 14 & 1060 \\
\hline 神奈川県 & 川崎市 & 14 & 1060 \\
\hline 新潟県 & 新潟市 & 41 & 619 \\
\hline 静岡県 & 静岡市 & 41 & 849 \\
\hline 静岡県 & 浜松市 & 41 & 849 \\
\hline 愛知県 & 名古屋市 & 14 & 1200 \\
\hline 京都府 & 京都市 & 41 & 518 \\
\hline 大阪府 & 大阪市 ${ }^{a}$ & 25 & 1140 \\
\hline 大阪府 & 堺市 ${ }^{a}$ & 25 & 1140 \\
\hline 兵庫県 & 神戸市 & 25 & 768 \\
\hline 広島県 & 広島市b & 42 & 445 \\
\hline 福岡県 & 北九州市 & 42 & 853 \\
\hline 福岡県 & 福岡市 & 42 & 853 \\
\hline
\end{tabular}

(a)トウモロコシ

a) 兵庫県の指針を準用; b) 岡山県の指針を準用

\begin{tabular}{|c|c|c|c|}
\hline 都道府県 & 都市 & $\begin{array}{c}\text { 施肥量 } \\
\text { [kgN/10a] }\end{array}$ & $\begin{array}{c}\text { 収量 } \\
{[\mathrm{kg} / 10 \mathrm{a}]}\end{array}$ \\
\hline 北海道 & 札幌市 & 10 & 236 \\
\hline 宮城県 & 仙台市 & 15 & 147 \\
\hline 埼玉県 & さいたま市 & 10 & 164 \\
\hline 千葉県 & 千葉市 & 15 & 120 \\
\hline 東京都 & 東京都区部 & 11 & 127 \\
\hline 神奈川県 & 横浜市 & 7.4 & 158 \\
\hline 神奈川県 & 川崎市 & 7.4 & 158 \\
\hline 新潟県 & 新潟市 ${ }^{a}$ & 10 & 138 \\
\hline 静岡県 & 静岡市 & 10 & 119 \\
\hline 静岡県 & 浜松市 & 10 & 119 \\
\hline 愛知県 & 名古屋市 & 6.8 & 176 \\
\hline 京都府 & 京都市 & 41 & 76 \\
\hline 大阪府 & 大阪市 ${ }^{b}$ & 14 & 126 \\
\hline 大阪府 & 堺市b & 14 & 126 \\
\hline 兵庫県 & 神戸市 & 14 & 129 \\
\hline 広島県 & 広島市 & 14 & 136 \\
\hline 福岡県 & 北九州市 ${ }^{c}$ & 10 & 189 \\
\hline 福岡県 & 福岡市c & 10 & 189 \\
\hline
\end{tabular}

(b) 大豆

a) 富山県の指針を準用;b) 兵庫県の指針を準用;c)佐賀県の 指針を準用 
表-2 燃料作物の栽培と污泥利用シナリオ

\begin{tabular}{|c|c|c|c|c|c|}
\hline $\begin{array}{l}\text { シナ } \\
\text { リオ }\end{array}$ & 燃料作物 & $\begin{array}{l}\text { 利用する下水污泥の排 } \\
\text { 出源 }\end{array}$ & 污泥堆肥の利用量 & 栽培地 & $\begin{array}{l}\text { 現在の作 } \\
\text { 付作物か } \\
\text { らの転作 }\end{array}$ \\
\hline SC-1 & トウモロコシ & $\begin{array}{l}\text { 政令指定都市または特 } \\
\text { 別区運営の下水処理場 }\end{array}$ & 全量 & $\begin{array}{l}\text { 政令指定都市または特別区の } \\
\text { ある都道府県および隣接地域 } \\
\text { の農地 }\end{array}$ & する \\
\hline SC-2 & トウモロコシ & $\begin{array}{l}\text { 政令指定都市または特 } \\
\text { 別区運営の下水処理場 }\end{array}$ & $\begin{array}{l}\text { 同一都道府県内の耕作放棄地 } \\
\text { と経営耕地で利用可能な量 }\end{array}$ & $\begin{array}{l}\text { 政令指定都市または特別区の } \\
\text { ある都道府県の農地 }\end{array}$ & する \\
\hline SC-3 & トウモロコシ & $\begin{array}{l}\text { 政令指定都市または特 } \\
\text { 別区運営の下水処理場 }\end{array}$ & $\begin{array}{l}\text { 同一都道府県内の耕作放棄地 } \\
\text { で利用可能な量 }\end{array}$ & $\begin{array}{l}\text { 政令指定都市または特別区の } \\
\text { ある都道府県の耕作放棄地 } \\
\end{array}$ & しない \\
\hline SB-1 & 大豆 & $\begin{array}{l}\text { 政令指定都市または特 } \\
\text { 別区運営の下水処理場 }\end{array}$ & 全量 & $\begin{array}{l}\text { 政令指定都市または特別区の } \\
\text { ある都道府県および隣接地域 } \\
\text { の農地 }\end{array}$ & する \\
\hline SB-2 & 大豆 & $\begin{array}{l}\text { 政令指定都市または特 } \\
\text { 別区運営の下水処理場 }\end{array}$ & $\begin{array}{l}\text { 同一都道府県内の耕作放棄地 } \\
\text { と経営耕地で利用可能な量 }\end{array}$ & $\begin{array}{l}\text { 政令指定都市または特別区の } \\
\text { ある都道府県の農地 }\end{array}$ & する \\
\hline SB-3 & 大豆 & $\begin{array}{l}\text { 政令指定都市または特 } \\
\text { 別区運営の下水処理場 }\end{array}$ & $\begin{array}{l}\text { 同一都道府県内の耕作放棄地 } \\
\text { で利用可能な量 }\end{array}$ & $\begin{array}{l}\text { 政令指定都市または特別区の } \\
\text { ある都道府県の耕作放棄地 }\end{array}$ & しない \\
\hline
\end{tabular}

リ $2.2 \%$ と ${ }^{11)}$, 肥効率は, 窒素 0.3 , リン酸 0.5 , カリ 0.9 とした ${ }^{20)}$. 污泥堆肥の成分組成は，窒素 $2.7 \%$, リン酸 $3.2 \%$ ，カリ $0.4 \%$ とした ${ }^{4}$. 污泥堆肥の肥効率は，窒素 0.65 とし ${ }^{23)}$ ，リン酸とカリ は牛糞堆肥と同等と仮定した. 化成肥料との代替率は, 窒素を 0.3 , リン酸とカリは 1.0 とした ${ }^{12)}$. なお，トウモロコシについては，大阪府およ び広島県の施肥基準に関する情報が得られなかったため, それぞれ京都府および岡山県の施肥基準を基にし，大豆 に関しては，新潟県，静岡県，大阪府および福岡県の施 肥基準に関する情報が得られなかったため，それぞれ富 山県, 愛知県, 京都府および佐賀県の施肥基準を準用し た.

\section{（3）エタノール収量, 発熱量および温室効果ガス排出削 減効果}

トウモロコシからのエタノール収量および大豆からの バイオディーゼル（BDF）収量については，それぞれエ タノール1 Lあたり 2.69 kgのトウモロコシ, BDF 1000 kg あたり5,556 kg の大豆が必要と仮定した24).エタノール の発熱量は 0.02133 GJ/L, BDFの発熱量は0.3574 GJ/kg とし た ${ }^{24}$. バイオ燃料生産投入エネルギーは，生産エネルギ 一を1としたとき, トウモロコシ由来のエタノール生産 の場合で 0.62-1.29 2429), 大豆由来のBDFの場合で $0.27^{24)}$, $0.31^{29)} ， 1.32^{30)}$ と報告されている. 本研究では，トウモロ コシおよび大豆における投入エネルギ一比として，これ ら文献の中間值である0.78と0.31 をそれぞれ用いた。な お，収穫されたトウモロコシのうち，エタノール生産に 利用可能な子実の割合は，収穫量の50\%とした。

また，生成したバイオエタノールとBDFはそれぞれガ ソリンと軽油に混合して利用するとした. ガソリンと軽 油の温室効果ガス排出原単位は それぞれ2.3, $2.6 \mathrm{kgCO}_{2} / \mathrm{L}$ とした ${ }^{31)}$. 軽油の比重は0.85とした。

\section{（4）燃料作物の栽培シナリオ}

トウモロコシ，大豆それぞれについて，後述の3つの 污泥利用・栽培シナリオを策定し, 計6シナリオ（表2）に基づいて温室効果ガス排出削減ポテンシャルを計 算した. 各都道府県における経営耕地面積および耕作放 棄地の面積は農林業センサス ${ }^{32}$ より得た。 全国の経営耕 地面積は3.61 百万ha, 耕作放棄地面積は385 千ha であっ た.

[栽培シナリオ1] 政令指定都市または特別区のある都道 府県の下水処理場から排出される下水污泥の全量を 堆肥化して燃料作物を栽培する. 耕作放棄地のみで 污泥堆肥が全量利用できない場合は, 経営耕地の作 物を燃料作物入転作して污泥堆肥を利用する。同一 都道府県内の耕作放棄地と経営耕地で消費できない 場合は，隣接する都道府県で利用する.

[栽培シナリオ2] 政令指定都市または特別区のある都道 府県の農地および耕作放棄地に, 下水污泥を利用し た堆肥を利用して燃料作物を栽培する。耕作放棄地 のみで污泥堆肥が全量利用できない場合は, 経営耕 地の作物を燃料作物へ転作して污泥堆肥を利用する。 污泥は，排出元の政令指定都市または特別区と同一 都道府県内の耕作放棄地と経営耕地で利用可能な量 だけ堆肥化する.

[栽培シナリオ3] 政令指定都市または特別区のある都道 府県の耕作放棄地に，下水污泥を利用した堆肥を利 用して燃料作物を栽培する。污泥は, 排出元の政令 指定都市または特別区と同一都道府県内の耕作放棄 地で利用可能な量のみ堆肥化する. 経営耕地の作物 を然料作物への転作はしない. 


\section{3. 結果}

（1）トウモロコシを燃料作物として栽培した場合

a) 政令指定都市および特別区の下水処理場の発生污泥 全量を栽培に利用した場合（シナリオSC-1）

政令指定都市および特別区の下水処理場から発生す る污泥全量をトウモロコシ栽培に利用したと仮定した場 合，収穫量で2.11千 kt，エタノール換算で 393 千 $\mathrm{kL}$ の卜 ウモロコシが栽培可能であった. 生成したバイオエタノ 一ルをガソリン代替として利用するとした場合，年間 904 kt- $\mathrm{CO}_{2}$ に相当するエタノールが生産できると試算さ れた. エタノール生産に必要な投入エネルギーを差し引 くと年間 199 kt-CO 2 の温室効果ガス排出削減効果があり, これは下水処理部門からの温室効果ガス排出量の $2.9 \%$ に 相当した.

b) 政令指定都市および特別区の下水処理場の発生污泥 を各都道府県内の耕作放棄地と経営耕地に栽培した 場合（シナリオSC-2）

政令指定都市および特別区の下水処理場から発生する 污泥を, 同一都道府県内の経営耕地と耕作放棄地ででき る限り利用してトウモロコシ栽培を行った場合, 収穫量 で862 kt，エタノール換算で160 千 kL のトウモロコシが 栽培可能であることが分かった. 生成したバイオエタノ 一ルをガソリン代替として利用するとした場合，エタ～ 一ル生産に必要な投入エネルギーを差し引くと年間 81.1 $\mathrm{kt}-\mathrm{CO}_{2}$ の温室効果ガス排出削減効果があり，これは下水 処理部門からの温室効果ガス排出量の $1.2 \%$ に相当した. 栽培する農地については, 東京都, 神奈川県, 大阪府で は，同一都府県内の耕作放棄地と経営耕地すべてを然料 作物栽培に利用したとしても発生した污泥全量を利用す るには不足していた（図-2）. c) 政令指定都市および特別区の下水処理場の発生污泥 を各都道府県内の耕作放棄地のみに栽培した場合 (シナリオSC-3)

政令指定都市および特別区の下水処理場から発生する 污泥を, 同一都道府県内の耕作放棄地すべてをトウモロ コシ生産に利用した場合, 収穫量で433 kt, エタノール 換算で80.5 千 kL 相当のトウモロコシが収穫可能と試算 された.このときすべての耕作放棄地に作付を行っても 污泥堆肥を全量消費できなかった都道府県は, 東京都, 神奈川県, 愛知県, 京都府, 大阪府であった. 生成した バイオエタノールをガソリン代替として利用するとした 場合, エタノール生産に必要な投入エネルギーを差し引 $<と 40.7 \mathrm{kt}-\mathrm{CO}_{2}$, 下水処理部門からの温室効果ガス排出 量の $0.60 \%$ にたる温室効果ガス排出削減効果があるこ とが分かった.

（2）大豆を燃料作物として栽培した場合

a) 政令指定都市および特別区の下水処理場の発生污泥 全量を栽培に利用した場合（シナリオSB-1）

政令指定都市および特別区の下水処理場から発生する污 泥全量を大豆を栽培した場合，収穫量で 958 kt，BDF 換 算で 172 千 $\mathrm{t}$ の大豆が栽培可能であることが分かった. 生成した BDF を軽油代替として利用するとした場合, $\mathrm{BDF}$ 生産に必要な投入エネルギーを差し引くと年間 274 $\mathrm{kt}-\mathrm{CO}_{2}$ の温室効果ガス排出削減効果があり, 下水処理部 門からの温室効果ガス排出量の $4.0 \%$, 日本の総排出量 の $0.020 \%$ に相当した.

b) 政令指定都市および特別区の下水処理場の発生污泥 を各都道府県内の耕作放棄地と経営耕地に栽培した 場合（シナリオ SB-2）

政令指定都市および特別区の下水処理場から発生す る污泥を, 同一都道府県内の経営耕地と耕作放棄地でで きる限り利用して大豆を栽培した場合, 収穫量で $324 \mathrm{kt}$,

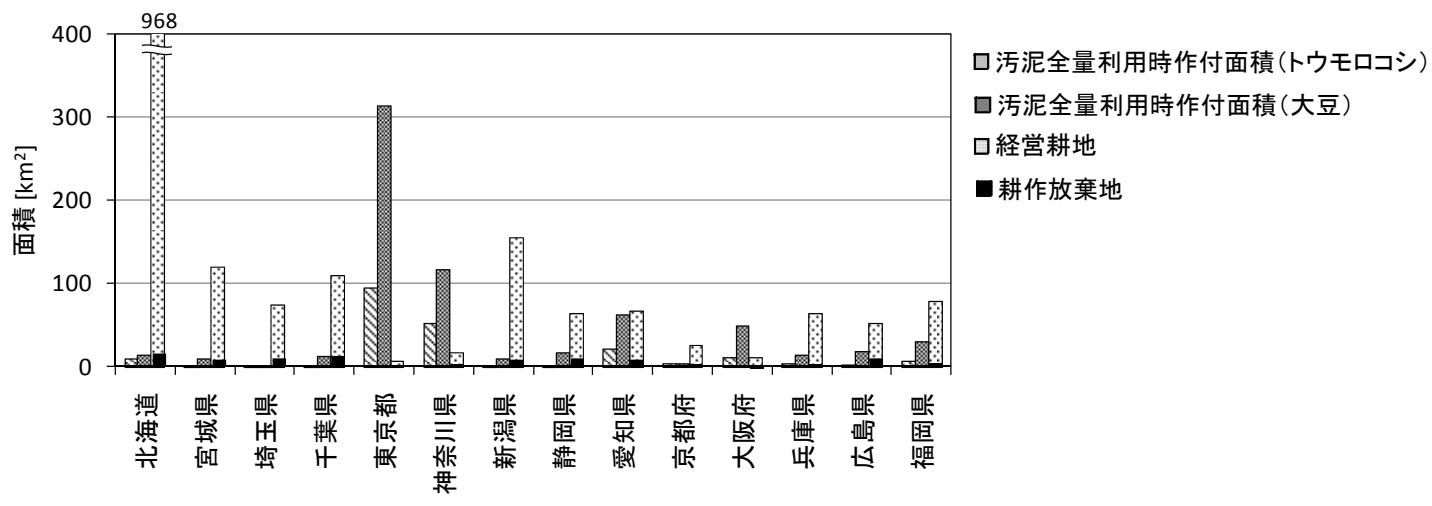

図-2 污泥堆肥を政令指定都市および特別区運営の下水処理場から排出される下水污泥を同一都道府県内で全量利用するために必 要な燃料作物の作付面積と各都道府県の経営耕地および耕作放棄地の面積 


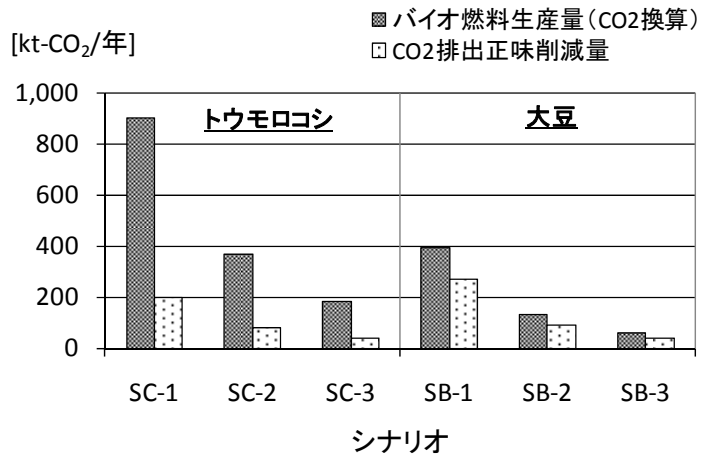

図-3 各シナリオのバイオ然料生産量と投入エネルギーを差し 引いた温室効果ガス排出の正味削減量

BDF換算で 58.3 千t の大豆が栽培可能であることが分か った．生成したBDFを軽油代替として利用するとした場 合，BDF生産に必要な投入エネルギーを差し引くと年間 $92.5 \mathrm{kt}-\mathrm{CO}_{2}$ の温室効果ガス排出削減効果があり, 下水処 理部門からの温室効果ガス排出量の $1.4 \%$ に相当した. 栽 培する農地については，トウモロコシの場合と同様，東 京都，神奈川県，大阪府では，同一都府県内の耕作放棄 地と経営耕地すへててを燃料作物栽培に利用したとしても 発生した污泥全量を利用寸るには不足していた（図-2）。

c) 政令指定都市および特別区の下水処理場の発生污泥 を各都道府県内の耕作放棄地に栽培した場合（シナ リオSB-3)

政令指定都市および特別区の下水処理場から発生す る污泥を，同一都道府県内の耕作放棄地すべてを大豆生 産に利用した場合，収穫量で149 kt，BDF換算で26.7千t 相当の大豆が収穫可能と試算された。また，生成した BDFを軽油代替として利用するとした場合，BDF生産に 必要な投入エネルギーを差し引くと42.4 kt- $\mathrm{CO}_{2}$, 下水処 理部門からの温室効果ガス排出量の0.62\%にあたる温室 効果ガス排出削減効果があることが分かった.

\section{4. 考察}

比較した 3 シナリオのうち, 最も温室効果ガス排出量 削減効果が大きかったシナリオ SB-1 において，下水処 理部門の $4.0 \%$ （日本全体の $0.020 \%$ ）に相当する年間約 $274 \mathrm{kt}-\mathrm{CO}_{2}$ の温室効果ガス排出量削減効果があることが 分かった．政令指定都市および特別区の下水処理場に太 陽光発電および小型風力発電を導入した場合の二酸化炭 素削減効果はそれぞれ年間 $278 \mathrm{kt}-\mathrm{CO}_{2}, 9.9 \mathrm{kt}-\mathrm{CO}_{2}$ であった 33) ことを考慮すると, 下水污泥を燃料作物に利用するこ とは一定の削減ポテンシャルがあるといえる．しかし， 污泥堆肥の利用を同一都道府県内に限定した場合には,

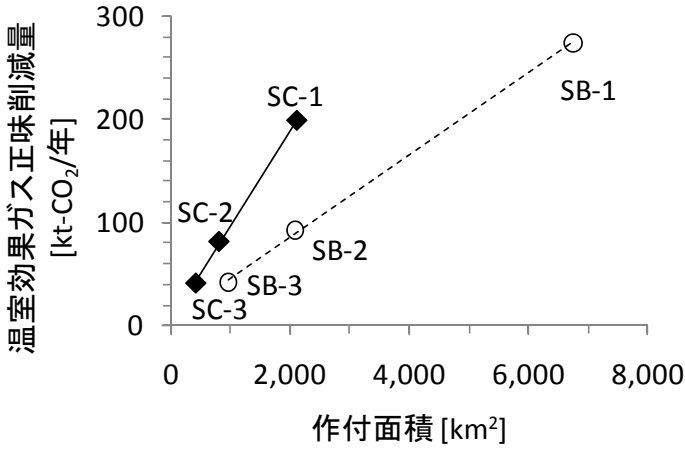

図-4 各シナリオにおける燃料作物の作付面積と温室効果ガス 排出の正味削減量

経営耕地を利用しても削減量が小さくなり，トウモロコ シと大豆の場合でそれぞれ81.1 kt- $\mathrm{CO}_{2}$ （下水処理部門の $1.2 \%$ および $92.5 \mathrm{kt}-\mathrm{CO}_{2}$ （下水処理部門の1.4\%）となっ た. 特に, 大都市を有する都府県（東京都, 神奈川県, 大阪府）では, 污泥堆肥生産可能量と農地での利用可能 量の差が大きく，隣接する都道府県への広域輸送が必要 となるため, 輸送コストの面から污泥堆肥の有効活用が 比較的困難であると考えられる。一方，耕作放棄地のみ で下水污泥を利用した場合の削減量は, トウモロコシの 場合で $40.7 \mathrm{kt}-\mathrm{CO}_{2}$ （下水処理部門の $0.60 \%$ 相当），大豆の 場合で $42.4 \mathrm{kt}-\mathrm{CO}_{2}$ （下水処理部門の0.62\%相当）であった. 本研究では, 農林業センサスで耕作放棄地として登録さ れている面積を用いて試算を行ったが, 経営耕地として 登録していながら実際には耕作を行っていない農地も存 在する2)。そのような農地も栽培地として確保できれば, さらなる削減量が見込める可能性はある.しかしながら， 経営耕地を利用した燃料作物栽培を行わない場合には, 削減効果は限定的であった。

生成したバイオ燃料は，ガソリンおよび軽油代替と して利用すると仮定したが，平成19年度の日本国内のガ ソリン販売量はそれぞれ60.1 百万kL および44.2 百万 $\mathrm{kL}$ であり ${ }^{34)}$ ，トウモロコシからエタノールを生産したシナ リオで生産量が最も多いシナリオSC-1のエタノール生産 量はガソリン販売量の $0.65 \%$ に相当し, 全国のガソリン の4分の1をE3（エタノールを3\%含むガソリン）にする ことで消費可能な量であった，一方，エタノール生産量 の最も小さいシナリオSC-3での生産量はガソリン販売量 の0.13\%に相当し，全国のガソリンの5\%をE3（エタノー ルを3\%含むガソリン）にすることで消費可能な量であ った. また, 大豆からBDFを生産した シナリオでは, 最も多いSB-1で軽油販売量の0.46\%, 最も少ないSB-3で 0.071\%であり，それぞれ全国の軽油の10\%と1.5\%をB5 （BDFを5\%含む軽油）にすることで消費可能な量であ った. 
トウモロコシと大豆では, どのシナリオにおいても, 大豆の方が温室効果ガスの正味削減量が大きくなった

（図-3）。面積当たりの収量は全国平均でトウモロコシ （子実）が 500 kg/10a，大豆が 164 kg/10a と約 3倍の差が あり 6, カ, また, $1 \mathrm{t}$ の燃料作物子実から生産されるエネ ルギー量はトウモロコシの方が大きいため, 同じ作付面 積であればトウモロコシの方が温室効果ガスの正味削減 量が大きかった（図-4）。しかしながら，面積当たりの 施肥量はトウモロコシの方が平均で 2.5 倍大きく, 大都 市のある都道府県（東京都，神奈川県，大阪府）以外で は污泥発生量が作付面積の制限因子となった（図-2）た めに，大豆の方がより多くの温室効果ガス排出削減が見 込める結果となった。

なお，今回の試算では生污泥および污泥堆肥の輸送 に必要エネルギーは考慮していないため、より詳細な削 減効果を計るためにはそれらも考慮する必要がある。ま た、このような施策の実現には，費用面の試算と施策を 支援する社会制度設計も不可欠であろう。

本研究で用いたバイオ燃料生産における投入エネル ギーについての原単位は，主に欧米での研究に基づいた ものであり，より日本での栽培・燃料生産に基づいた原 単位の精査が必要である。 また，日本においては，作付 経験の豊富な米も有望な燃料作物の一つであると考えら れる ${ }^{35}$ 30). 米からのバイオエタノール生産時の投入エネ ルギーの割合はトウモロコシと比べて大きいと報告され

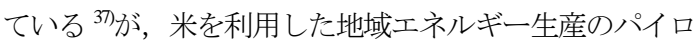
ットプロジェクトもいくつかの地域で行われており，今 後，污泥堆肥を用いて飼料米などからのバイオエタノー ル生成を行った場合の温室効果ガス排出量削減効果の試 算も必要であろう.

\section{5. 結論}

最も削減効果の大きかった政令指定都市および特別区 にある下水処理場から排出される污泥全量を堆肥化して 大豆を栽培しバイオディーゼルを生産した場合には，下 水処理部門の $4.0 \%$ （日本全体の0.020\%）に相当する温室 効果ガス排出量削減のポテンシャルがあることがわかっ た。一方で，同一都道府県の耕作放棄地の夕を燃料作物 栽培に用いた場合の削減量は, トウモロコシと大豆の場 合でそれぞれ下水処理部門の0.60\%，0.62\%にとどまった.

トウモロコシと大豆では，作付面積当たりの温室効果 ガス正味削減量はトウモロコシを栽培した方が大きかっ た.しかし，面積当たりの施肥量はトウモロコシの方が 平均で2.5倍大きく, 大都市のある都道府県（東京都, 神奈川県，大阪府）以外では污泥発生量が作付面積の制
限因子となったために，全体としては大豆の方がより多 くの温室効果ガス排出削減が見込める結果となった.

謝辞 : 本研究は土木学会・下水道施設を核としたエネル ギー・バイオマス利活用システムの最適化に関する小委 員会, 文部科学省・科学技術振興調整費およびJST-JICA 地球規模課題対応国際科学技術協力（SATREPS）の支 援により行われた。

\section{参考文献}

1) 国土交通省：下水道における地球温暖化防止推進計画策定 の手引き,p.95, 2007.

2）農林水産省：かけがえのない農地を守るために一耕作放衰 地対策推進の手引き-,2010.

3) 日本下水道協会: 平成19年度版下水道統計 (第64号), 2009 .

4) 日本下水道協会: 下水污泥の農地・緑地利用マニュアル, p.21, 2005.

5) Kirchmann $\mathrm{H}$ : Losses, plant uptake and utiliization of manure nitrogen during a production cycle. Acta Agriculture Scandinavica Supplement Vol. 24, pp.1-77, 1985.

6) 農林水産統計デー夕: 平成19年産秋冬野菜, 指定野菜に準 ずる野菜等の作付面積, 収穫量及び出荷量, 2008 .

7) 農林水産統計データ: 平成19年産大豆の収穫量,2008.

8）北海道農政部: 北海道施肥ガイド2002.

9)宮城県:タやぎの野菜指導指金+,2006.

10）埼玉県農林部経営普及課: 主要農作物施肥基準, 1988 .

11) 神奈川県環境農政部農業振興課: 神奈川県作物別肥料施用 基準（15訂版）,2004.

12）千葉県: 主要農作物等施肥基淮, 2004.

13）東京都産業労働局農林水産部:農作物施肥基準一穀物・野 菜・果樹・花き・茶一, 2003 ,

14) 新潟県: 野菜栽培指針, 2003.

15）富山県農林水産部: 平成17年度水稲・大豆 $・$ 大麦栽培技術 指針, 2005 .

16) 静岡県: 持続的農業を推進する静岡県土壤肥料ハンドブッ ク,2005.

17) 愛知県: 農作物の施肥基淮, 2006 .

18）京都府農林水産部 : 京都府における環境にやさしい農業推 進のための技術指針 No.2,2000.

19）兵庫県: 環境負荷軽減に配慮した各種作物の施肥基隻,2003.

20) 岡山県: 野菜栽培指金十, 2001.

21）福岡県農政部農業技術課: 福岡県野菜施肥基淮, 2006.

22) 佐賀県: 平成17年度施肥・病害虫防除・雑草防除のてびき $<$ 水稲・大豆・果樹・茶 $>, 2004$.

23）農林水産省消費・安全局: 污泥肥料の規制のあり方に関寸 万懇談会報告書, 2009

24) Pimentel D. and Patzek T.W. : Ethanol Production Using Com, Switch- 
grass, and Wood; Biodiesel Production Using Soybean and Sunflower. Natural Resources Research, Vol. 14, No.1, pp.65-76, 2005.

25) Jason Hill, Erik Nelson, David Tilman, Stephen Polasky and Douglas Tiffany : Environmental, economic, and energetic costs and benefits of biodiesel and ethanol biofuels. PNAS Vol. 103 No. 30, pp.11206-11210, 2006.

26) Hammerschlag, R. : Ethanol's energy retum on investment: A survey of the literature 1990-Present. Environmental Science \& Technology, Vol. 40, No. 6, pp.1744-1750, 2006.

27) Kim, S. and Dale, B. : Environmental aspects of ethanol derived from no-illed com grain: nonrenewable energy consumption and greenhouse gas emissions. Biomass and Bioenergy, Vol.28, No. 5, pp.475-489, 2005

28) Marland, G. and Turhollow, A : $\mathrm{CO}_{2}$ emissions from the production and combustion of fuel ethanol from com. Energy, Vol.16, No.11-12, pp.1307-1316, 1991.

29) Shapouri, H., Duffield, J. A., and Wang, M. : The energy balance of com ethanol: an update. Agricultural Economics Reports. United States Department of Agriculture, 2002.

30) Sheehan, J., Camobreco, V., Duffield, J., Shapouri, H., Graboski, M., and Tyson, K. : An overview of biodiesel and petroleum diesel life cycles, National Renewable Energy Lab., Golden, CO(US), 2000.
31）環境情報科学センター： $\mathrm{CO}_{2}$ 排出原単位表（2007年版）， 2007/1/12, 2007.

32) 農林業センサス: 第 2 巻 農林業経営体調查報告書（総括 編) ,2005.

33）本多了, 福士謙介：下水処理場の敷地を利用した太陽光発 電・小型風力発電導入によるエネルギー創出ポテンシャ ル.土大学会論文集G.,2011. (印刷中)

34) 経済産業省 : 経済産業省生産動態統計（資源・エネルギー 統計）年報 平成19年度, 2008 .

35）野口良造，小山瑞樹 : 地域循環型バイオマスエネルギーに よる自動車用エネルギー代替の可能性. 農業情報研究, Vol.18, No.3, pp. 142-151, 2009.

36) Saga K., Imou K., Yokoyama S. and Minowa T. : Net energy analysis of bioethanol production system from high-yield rice plant in Japan, Applied Energy, Vol. 87, pp. 2164-2168, 2010.

37) 下ヶ橋雅樹, 佐藤将, 迫田章義 : エネルギー作物利活用にお ける水環境負荷とエネルギー収支，環境科学会誌，Vol.21， No.5, pp.379-390, 2008.

(2011.8.8 受付)

\section{POTENTIAL OF GREENHOUSE GASES REDUCTION BY FUEL CROP CULTIVATION UTILIZING SEWAGE SLUDGE IN JAPAN}

\section{Ryo HONDA and Kensuke FUKUSHI}

Potential of greenhouse gases (GHG) reduction was estimated and compared in six scenarios of fuel crop cultivation by utilizing sewage sludge in Japan. Bioethanol from corn and biodiesel fuel from soybean was selected as biofuel produced. When all the sludge discharged from sewage treatment plants in 18 major cities was utilized for soybean cultivation and subsequent biodiesel fuel production, produced biofuel corresponded to $4.0 \%$ of GHG emitted from sewage treatment in Japan. On the other hand, cultivation area for fuel crop cultivation was found to be the regulating factor. When fuel crop was cultivated only in abandoned agricultural fields, produced biofuel corresponded to $0.60 \%$ and $0.62 \%$, respectively, in the case that corn and soybean was cultivated. Production of biodiesel fuel from soybean was estimated to have more net reduction potential than bioehanol production from corn when sludge production is limited, because required sewage sludge compost was 2.5-times larger in corn although reduction potential per crop area was 2-times larger in bioethanol production from corn. 